Vol. 45, N. 1 : pp. 53 - 58, March, 2002

ISSN 1516-8913 Printed in Brazil

BRAZILIAN ARCHIVES OF BIOLOGY AND TECHNOLOGY

AN INTERNATIONAL JOURNAL

\title{
Nymph and Adult Performance of the Small Green Stink Bug, Piezodorus guildinii (Westwood) on Lanceleaf Crotalaria and Soybean
}

\author{
Antônio Ricardo Panizzi ${ }^{1 *}$; Shirlei Regina Cardoso $^{1}$ and Viviane Ribeiro Chocorosqui ${ }^{2}$ \\ ${ }^{1}$ Centro Nacional de Pesquisa de Soja (CNPSo), Empresa Brasileira de Pesquisa Agropecuária (Embrapa), Caixa \\ Postal 231, Londrina, Paraná 86001-970; ${ }^{2}$ Universidade Federal do Paraná (UFPR), Departamento de Zoologia, \\ Caixa Postal 19020, Curitiba - PR, Brazil
}

\begin{abstract}
Lanceleaf crotalaria, Crotalaria lanceolata E. Mey (Leguminosae) was found hosting the small green stink bug, Piezodorus guildinii (Westwood), in Paraná State, Brazil. In the laboratory, nymphs showed less mortality when fed on immature pods of crotalaria (64\%) than when fed on immature pods of soybean, Glycine max (L.) Merrill (88\%). From 2nd stadium to adult, nymphs required less time to complete development on crotalaria (mean of females and males $=18.4$ days) than on soybean (21.5 days). Fresh body weight at adult emergence was greater on crotalaria (mean of females and males $=51.4 \mathrm{mg}$ ) than on soybean $(42.2 \mathrm{mg})$. Adult $\mathrm{P}$. guildinii tended to live longer on crotalaria than on soybean. Mean adult longevity was 34.6 days on crotalaria, and 28.8 days on soybean. However, the reproductive performance of females, although similar on both foods, tended to be greater on soybean. These results indicated that $\mathrm{P}$. guildinii was able to develop and reproduce on the wild host lanceleaf crotalaria. Compared to soybean, this weed plant was more suitable for nymph development, and equally suitable for adult reproduction.
\end{abstract}

Key words: Heteroptera, Pentatomidae, stink bug, Crotalaria lanceolata, Glycine max, food effect, biology

\section{INTRODUCTION}

The small green stink bug, Piezodorus guildinii (Westwood) (Hemiptera: Heteroptera: Pentatomidae) is a neotropical bug with several species of wild and cultivated plants (mostly legumes) referred to as food plants. Among the wild plants, legumes of the genus Indigofera are preferred (Panizzi, 1992), while among the cultivated plants, soybean, Glycine $\max$ (L.) Merrill is the most important host, throughout South America, and particularly in Brazil (Panizzi \& Slansky, 1985a).
Among the legume hosts, we have recently observed $P$. guildinii feeding and reproducing on the wild lanceleaf crotalaria, Crotalaria lanceolata E. Mey (Leguminosae) in Londrina (latitude $23^{\circ}$ 11' S, longitude $51^{\circ} 11^{\prime} \mathrm{W}$ ), in Paraná State of Brazil. This wild legume grows in abandoned areas and is common in pasture lands. It occurs all over the Brazilian territory, spreading northward as far as Florida in the United States (Lorenzi, 1982; A. R. Panizzi, personal observation). In Florida, $C$. lanceolata was found hosting $P$. guildinii and the adult biology of this bug has been investigated on

\footnotetext{
* Author for correspondence
} 
this wild host plant (Panizzi \& Slansky, 1985b). However, no data on the nymph biology of $P$. guildinii on lanceleaf crotalaria is available. Furthermore, the colonization of $P$. guildinii on lanceleaf crotalaria in the Londrina area, is an opportunity to compare how these populations (i.e., bugs and plants) interact compared to the data on the adult biology obtained in Florida. Therefore, a study was carried out on the nymph and adult performance of $P$. guildinii on lanceleaf crotalaria, using soybean, a plant commonly colonized by this bug, as comparison.

\section{MATERIAL AND METHODS}

Laboratory Study (Nymphs): During January and February 1999, adults of $P$. guildinii were obtained from a soybean culture established in the Embrapa Field Experiment Station at Londrina Co., northern Paraná. They were taken to the laboratory and placed in plastic boxes $(11.0 \times 11.0$ $x 3.5 \mathrm{~cm}$ ), and fed with soybean pods (immature) cv. 'BR-16'. Egg masses were collected on the day of oviposition and placed in $9.0 \times 1.5 \mathrm{~cm}$ Petri dishes with moistened filter paper. On 1st day of second stadium (first instars do not feed), nymphs were removed and placed individually in Petri dishes. Immature pods of lanceleaf crotalaria, $C$. lanceolata and soybean (cv. 'Paraná') were offered. Twenty five nymphs (replicates) were used for each food.

Petri dishes were placed at random in an environmental chamber maintained at $25 \pm 1{ }^{\circ} \mathrm{C}$ and $65 \pm 5 \%$ r.h. with a photoperiod of L14:D10. From March to April 1999, daily observations were made on moulting and mortality. Food was replaced every 2 days. Nymphal development time and percentage mortality from 2 nd instar to adult were calculated. Fresh body weight at adult emergence was taken using an electronic balance. Data on percentage nymph mortality were calculated. Data on nymphal development time and fresh body weight at adult emergence were analyzed and compared using student's $t$ test.

Laboratory Study (Adults): During March to May 1999, P. guildinii nymphs were collected using a sweep net from soybean cultivated at the Embrapa Field Experiment Station in Londrina. Nymphs were taken to the laboratory and placed in plastic rearing boxes $(12.0 \times 12.0 \times 3.8 \mathrm{~cm})$ covered with lids. Nymphs were fed immature pods of soybean. When nymphs reached adulthood, single female/male pairs were each placed in a plastic rearing box with moistened filter paper. Fifty pairs were fed immature pods of lanceleaf crotalaria and another 30 immature pods of soybean. Food was replaced every 2 days.

During April-May 1999, daily observations were made on adult survival and reproduction. Total longevity of adults and percentage survivorship of females and males up to day 50 were calculated. Percent females ovipositing, female age at first oviposition, mean number of egg masses and eggs/female, and percentage egg hatch were calculated. Data of longevity and reproductive parameters on both foods were analyzed and compared using student's $t$ test.

\section{RESULTS AND DISCUSSION}

Laboratory Study (Nymphs): Nymphal development time for each stadium and for total nymphal period (stadia 2 through 5) was, in general, significantly greater on soybean than on lanceleaf crotalaria (Table 1). For 4th and 5th stadia, nymphs took significantly longer time on soybean than on crotalaria to complete development; for 3rd stadium, nymphs also tended to develop slower on soybean. Only on 2nd stadium nymphs developed slower on crotalaria compared to soybean. Total nymphal period was significantly longer for nymphs fed soybean pods compared to those fed crotalaria pods (Table 1). Total nymphal mortality was greater on soybean $(88 \%)$ than on crotalaria $(64 \%)$. Greater mortality of nymphs occurred during the 2 nd instar on both foods, decreasing thereafter (Table 1).

At adult emergence, females were heavier on crotalaria than on soybean; males, however, showed similar weight on both foods, and tended to be heavier on soybean (Table 1).

These data on nymphal developmental time, body weight at adult emergence, and nymph mortality, indicated that soybean was a less suitable food for nymphs than crotalaria. The nymph developmental time from 2 nd stadium to adult of about 18.4 days on crotalaria is usually shorter than that reported on other foods in other studies under similar conditions (range of 20.2 to 30.3 days); the mean value obtained in soybean (21.5 days) is more similar to those reported on this same food (range of 19.7 to 21.2 days; Panizzi \& Smith 1977; Panizzi, 1987; 1992). 
The nymph mortality observed on the latter (64\%), although high, is similar to that observed on other legumes, such as Indigofera hirsuta L. (58.3\%), and less than that observed on I. suffruticosa Mill. (84.2\%; Panizzi, 1992), which is more similar to what was observed on soybean (88.0\%). The smallest values on $P$. guildinii nymph mortality have been observed on the legumes I. endecaphylla Jacq. (12\%) and on Sesbania aculeata (Willd.) Pers. (25\%) (Panizzi, 1987).

Table 1 - Mean \pm SEM developmental time, \% nymph mortality, and fresh body weight of 1-day-old adult Piezodorus guildinii feeding on immature pods of lanceleaf crotalaria or soybean in the laboratory.

\begin{tabular}{|c|c|c|c|c|c|c|c|c|}
\hline \multirow[t]{2}{*}{ Food $^{2}$} & \multicolumn{4}{|c|}{ Stadium duration, $\mathrm{d}^{1}$} & \multicolumn{2}{|c|}{$\begin{array}{c}\text { Total developmental } \\
\text { time, } \mathrm{d}^{1,4}\end{array}$} & \multicolumn{2}{|c|}{$\begin{array}{c}\text { Fresh body weight, } \\
\mathrm{mg}^{1}\end{array}$} \\
\hline & 2 nd & $3 \mathrm{rd}$ & 4th & 5 th & Female & Male & Female & Male \\
\hline $\begin{array}{l}\text { Lanceleaf } \\
\text { crotalaria }\end{array}$ & $\begin{array}{c}4.8 \pm 0.23 \mathrm{a} \\
{[18]^{3}} \\
(28.0)^{5}\end{array}$ & $\begin{array}{c}4.1 \pm 0.27 a \\
{[14]} \\
(16.0)\end{array}$ & $\begin{array}{c}3.6 \pm 0.20 b \\
{[11]} \\
(12.0)\end{array}$ & $\begin{array}{l}6.5 \pm 0.38 \mathrm{~b} \\
{[9]} \\
(8.0)\end{array}$ & $\begin{array}{l}18.2 \pm 0.49 b \\
\quad[5] \\
\quad(64\end{array}$ & $\begin{array}{l}18.7 \pm 1.44 b \\
.4)^{6}\end{array}$ & $\begin{array}{c}58.4 \pm 1.17 \mathrm{a} \\
{[5]}\end{array}$ & $\begin{array}{c}44.5 \pm 4.63 a \\
{[4]}\end{array}$ \\
\hline Soybean & $\begin{array}{c}4.5 \pm 0.31 \mathrm{~b} \\
{[14]} \\
(44.0)^{5}\end{array}$ & $\begin{array}{c}4.5 \pm 0.60 \mathrm{a} \\
{[9]} \\
(20.0)\end{array}$ & $\begin{array}{c}4.7 \pm 0.48 \mathrm{a} \\
{[4]} \\
(20.0)\end{array}$ & $\begin{array}{c}7.7 \pm 0.33 \mathrm{a} \\
{[3]} \\
(8.0)\end{array}$ & $\begin{array}{l}20.0 \mathrm{a} \\
{[1]} \\
\end{array}$ & $\begin{array}{c}23.0 \pm 0.00 \mathrm{a} \\
{[2]} \\
0)^{6}\end{array}$ & $\begin{array}{c}37.4 \mathrm{~b} \\
{[1]}\end{array}$ & $\begin{array}{c}47.5 \pm 3.50 \mathrm{a} \\
{[2]}\end{array}$ \\
\hline
\end{tabular}

\begin{abstract}
${ }^{\mathrm{T}}$ Means (in each column) followed by the same letter do not differ significantly according to student's $t$ test (P $\leq$ 0.05). ${ }^{2}$ Initial number of nymphs $n=25$ on each food. ${ }^{3}$ Brackets mean numbers surviving each stadium. ${ }^{4}$ From second stadium to adult. ${ }^{5}$ Parentheses mean percentage nymphal mortality. ${ }^{6}$ Percentage mortality from 2 nd-5th stadia.
\end{abstract}

The high mortality value obtained in soybean (88.5) is greater than that obtained on this food in other studies, such as $52.5 \%$ (Panizzi, 1987). Variation in mortality values on the same food wass likely to occur due to the variable quality of both, food and insects. However, for P. guildinii it is normal to obtain high mortalities in the laboratory on most foods, and this is suspected to occur also in the field.

The mean body weight of females and males at adult emergence of $51.4 \mathrm{mg}$ on crotalaria, was, in general, higher than that observed on most foods, such as Indigofera spp. (mean range of 32.8 to 43.3 mg; Panizzi, 1992). These values are more in agreement with the mean weight obtained on soybean, i.e., $42.2 \mathrm{mg}$.

Laboratory Study (Adults): In contrast to what was observed for nymphs, adult $P$. guildinii performed equally well when fed on crotalaria or soybean immature pods. Female and male longevities were similar on both foods, although they tended to live longer on crotalaria (mean longevity of 34.6 days) than on soybean (28.3 days;
Figure 1). Females survivorship up to day 50 decreased in a similar pattern on both foods, being slightly greater on crotalaria compared to soybean. At the end of the period of 50 days, less than $30 \%$ of the adults were alive on either food.

A similar number of females oviposited when reared on crotalaria $(32 \%)$ than when reared on soybean (30\%), and those that oviposited took 15 days longer to start oviposition when reared and maintained on crotalaria compared to soybean (Table 2).

Fecundity, although greater on soybean (3.4 egg masses and 42.4 eggs more) than on crotalaria, these differences were not statistically different $(\mathrm{P}<0.05)$. Percent egg hatch was also similar on both foods. In another study conducted in the laboratory with adult $P$. guildinii on lanceleaf crotalaria in Florida, USA, females showed a much greater reproductive performance on this food plant, compared to soybean (Panizzi \& Slansky, $1985 b)$. Perhaps, the population of bugs used was more adapted to crotalaria than the one used in this study. It is known that local populations of the same insect species may behave in a different 
pattern with respect to feeding preferences and performances (see Fox \& Morrow [1981] for further details about local populations that specialize on certain food plants). These data on $P$. guildinii adult performance indicated that although the differences observed for both foods, crotalaria and soybean were equally suitable, differing somewhat on the data observed for nymphs, which suggested a better performance of the bug on crotalaria.

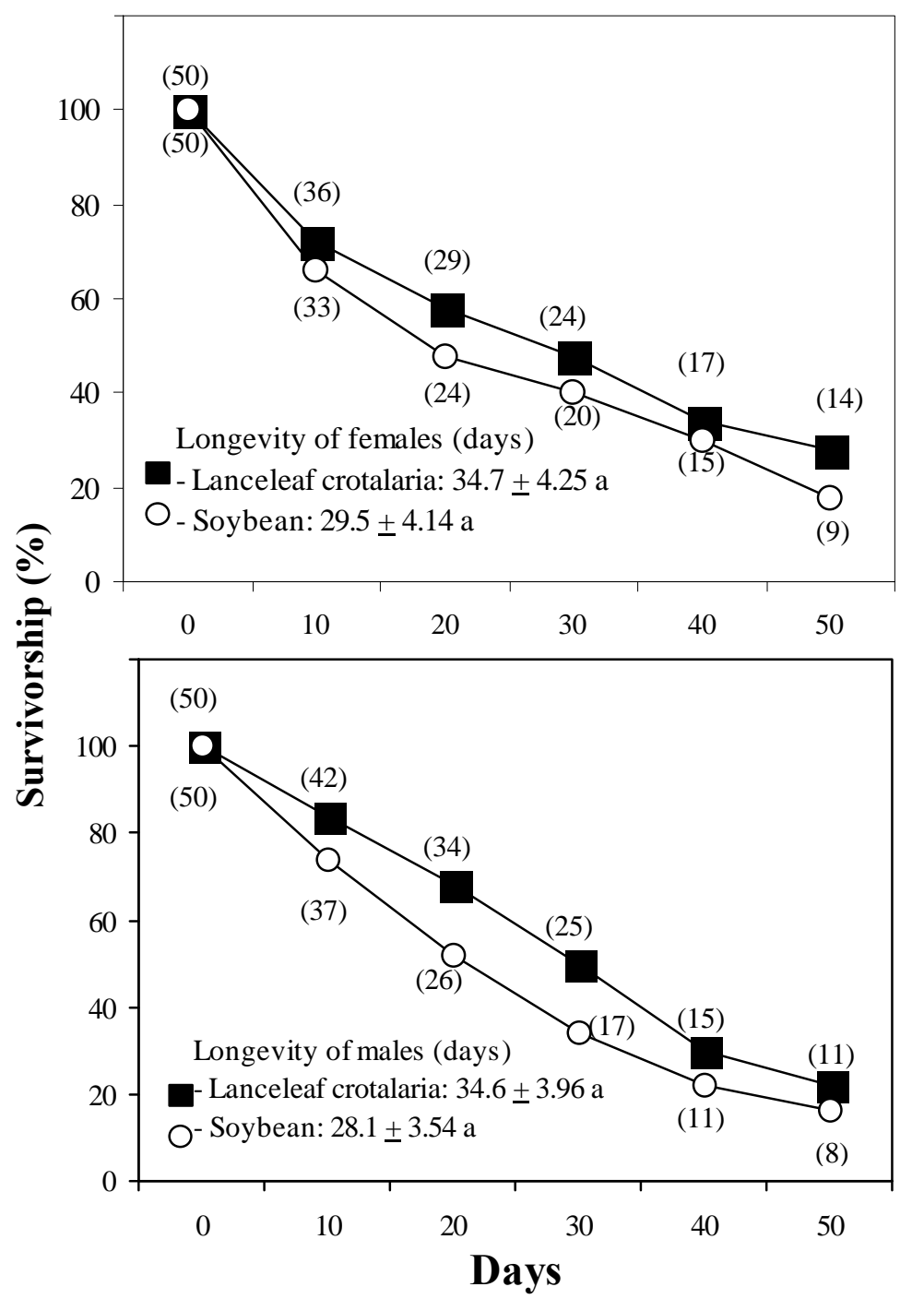

Figure 1 - Survivorship up to 50 days and total longevity of female and male Piezodorus guildinii feeding on immature pods of lanceleaf crotalaria or soybean in the laboratory (initial number on each food $n=50$; number of adults at each time interval in parentheses). No significant differences in longevity according to the student's $t$ test.

This is likely to occur, and studies have indicated that different foods vary to their suitability depending on the stage of development, and that food switch from nymph to adult is an important component of the nutritional ecology of heteropterans (references in Panizzi, 1997). In conclusion, these data indicated that crotalaria is an important component of the life history of the small 
green stink bug $P$. guildinii in the northern area of Paraná state. However, it is suspected that because crotalaria is not a very scattered pattern, it is more difficult to be located by the bugs and, therefore, to be more frequently colonized.

Table 2 - Reproductive performance of Piezodorus guildinii females feeding on immature pods of crotalaria or soybean in the laboratory (mean \pm standard error of the mean).

\begin{tabular}{lccccc}
\hline & Females & Female age (days) at & \multicolumn{2}{c}{ No. per female $^{1}$} & Egg \\
\cline { 4 - 5 } Food & $\begin{array}{c}\text { ovipositing } \\
\%\end{array}$ & first oviposition $^{1}$ & Egg masses & Eggs & hatch $(\%)^{1}$ \\
\hline $\begin{array}{r}\text { Lanceleaf } \\
\text { crotalaria }\end{array}$ & 32.0 & $29.7 \pm 3.49 \mathrm{a}$ & $3.6 \pm 0.66 \mathrm{a}$ & $36.3 \pm 8.19 \mathrm{a}$ & $71.7 \pm 10.04 \mathrm{a}$ \\
Soybean & {$[16]^{2}$} & & & & \\
& 30.0 & $27.7 \pm 3.08 \mathrm{a}$ & $7.0 \pm 1.87 \mathrm{a}$ & $78.7 \pm 25.91 \mathrm{a}$ & $62.0 \pm 10.18 \mathrm{a}$
\end{tabular}

\footnotetext{
${ }^{1}$ Means (in each column) followed by the same letter do not differ significantly according to student's $t$ test (P $\leq$ $0.05) .{ }^{2}$ Brackets $=$ number of female ovipositing.
}

Plant apparency is an important issue when considering plant location and colonization insects (see Feeny, 1976). Soybean, by being by cultivated in huge areas is more likely to be located by $P$. guildinii in comparison to the wild crotalaria. Unfortunately, no data are available to answer the question of how often crotalaria is colonized by $P$. guildinii in the field.

\section{ACKNOWLEDGMENTS}

We thank Norman Neumaier and Beatriz S. Corrêa-Ferreira for revising an early version of the manuscript. This study was sponsored by the Empresa Brasileira de Pesquisa Agropecuária (EMBRAPA), Centro Nacional de Pesquisa de Soja (CNPSo). S.R.C was supported by the Conselho Nacional de Desenvolvimento Científico e Tecnológico $(\mathrm{CNPq})$ through a grant to A.R.P. Approved for publication by the Technical Director of Embrapa-Soja as manuscript number 019/2000.

\section{RESUMO}

A crotalária nativa, Crotalaria lanceolata E. Mey. (Leguminosae) foi encontrada abrigando o percevejo verde pequeno, Piezodorus guildinii (Westwood), no Estado do Paraná, Brasil. Em laboratório, as ninfas tiveram uma sobrevivência maior quando alimentadas com vagens imaturas de crotalária (64,0\% de mortalidade) do que quando alimentadas com vagens imaturas de soja, Glycine $\max$ (L.) Merrill (88,0\% de mortalidade). Do segundo estádio ninfal à fase adulta, as ninfas requereram menos tempo para completar seu desenvolvimento em crotalária (média de fêmeas e machos $=18,4$ dias) do que em soja (21,5 dias). O peso corporal fresco na emergência dos adultos foi maior quando as ninfas alimentaram-se de vagens de crotalária (média de fêmeas e machos $=51,4$ $\mathrm{mg}$ ) do que quando se alimentaram de vagens de soja (42,2 mg). Os adultos de $P$. guildinii tenderam a viver por mais tempo em crotalária (34,6 dias) do que em soja (28,8 dias). Entretanto, a performance reprodutiva das fêmeas, embora semelhante nos dois alimentos, tendeu a ser superior em soja. Esses resultados indicam que as ninfas de $P$. guildinii se desenvolvem e os adultos se reproduzem na crotalária nativa. Os dados obtidos nesse estudo sugerem que, comparado à soja, a crotalária é mais adequada para o desenvolvimento das ninfas, não havendo, entretanto, diferença para a reprodução dos adultos.

\section{REFERENCES}

Feeny, P. P. (1976), Plant apparency and chemical defense. Recent Advances in Phytochemistry, 10(1), 1-40.

Fox, L. R. and Morrow, P. A. (1981), Specialization: 
species property or local phenomenon? Science 211, 887-893.

Lorenzi, H. (1982), Plantas daninhas do Brasil. Terrestres, aquáticas, parasitas, tóxicas e medicinais. Nova Odessa, SP: Edição do Autor, 425pp.

Panizzi, A. R. (1987), Impacto de leguminosas na biologia de ninfas e efeito da troca de alimento no desempenho de adulto de Piezodorus guildinii (Hemiptera: Pentatomidae), Revista Brasileira de Biologia, 47(4), 585-591.

Panizzi, A. R. (1992), Performance of Piezodorus guildinii on four species of Indigofera legumes. Entomologia Experimentalis et Applicata, 63(3), 221228.

Panizzi, A. R. (1997), Wild hosts of pentatomids: Ecological significance and role in their pest status on crops. Annual Review of Entomology, 42, 99-122.

Panizzi, A. R. and Slansky, F. (1985a), Review of phytophagous pentatomids (Hemiptera: Pentatomidae) associated with soybean in the Americas. Florida Entomologist, 68(1), 184-214.

Panizzi, A. R. and Slansky, F. (1985b), Legume host impact on performance of adult Piezodorus guildinii (Westwood) (Hemiptera: Pentatomidae), Environmental Entomology, 14(3), 237-242.

Panizzi, A. R. and Smith, J. G. (1977), Biology of Piezodorus guildinii: oviposition, development time, adult sex ratio, and longevity. Annals of the Entomological Society of America, 70(1), 35-39.

Received: April 10, 2000; Revised: October 18, 2000; Accepted: April 18, 2001. 